\title{
The resveratrol analogue, HS-1793, enhances the effects of radiation therapy through the induction of anti-tumor immunity in mammary tumor growth
}

\author{
JOONG SUN KIM ${ }^{1,2}$, SOO KYUNG JEONG ${ }^{2,3}$, SU JUNG OH ${ }^{2}$, CHANG GEUN LEE ${ }^{2}$, \\ YEONG ROK KANG ${ }^{2}$, WOL SOON JO ${ }^{2}$ and MIN HO JEONG ${ }^{3}$ \\ ${ }^{1}$ Herbal Medicine Resources Research Center, Korea Institute of Oriental Medicine, Naju-si, Jeollanam-do 58245; \\ ${ }^{2}$ Department of Research Center, Dong Nam Institute of Radiological and Medical Sciences, Jangan-eup, \\ Gijang-gun, Busan 619-953; ${ }^{3}$ Department of Microbiology, Dong-A University College of Medicine, \\ Seo-gu, Busan 602-714, Republic of Korea
}

Received September 10, 2019; Accepted February 25, 2020

DOI: $10.3892 / \mathrm{ijo} .2020 .5017$

\begin{abstract}
Radiotherapy can induce the infiltration of immune suppressive cells which are involved in promoting tumor progression and recurrence. A number of natural products with immunomodulating abilities have been gaining attention as complementary cancer treatments. This attention is partly due to therapeutic strategies which have proven to be ineffective as a result of tumor-induced immunosuppressive cells found in the tumor microenvironment. The present study investigated whether HS-1793, a resveratrol analogue, can enhance the antitumor effects by inhibiting lymphocyte damage and immune suppression by regulatory T cells (Tregs) and tumor-associated macrophages (TAMs), during radiation therapy. FM3A cells were used to determine the role of HS-1793 in the radiation-induced tumor immunity of murine breast cancer. HS-1793 treatment with radiation significantly increased lymphocyte proliferation with concanavalin A (Con A) stimulation and reduced the DNA damage of lymphocytes in irradiated tumor-bearing mice. The administration of HS-1793 also decreased the number of Tregs, and reduced interleukin (IL)-10 and transforming growth factor (TGF)- $\beta$ secretion in irradiated tumor-bearing mice. In addition, HS-1793 treatment inhibited CD206 ${ }^{+}$TAM
\end{abstract}

Correspondence to: Dr Wol Soon Jo, Department of Research Center, Dong Nam Institute of Radiological and Medical Sciences, Jwadong-gil 40, Jangan-eup, Gijang-gun, Busan 619-953, Republic of Korea

E-mail: sailorjo@dirams.re.kr

Professor Min Ho Jeong, Department of Microbiology, Dong-A University College of Medicine, Daeshingongwon-gil 32, Seo-gu, Busan 602-714, Republic of Korea

E-mail: mhjeong@dau.ac.kr

Key words: radiotherapy, HS-1793, resveratrol analogue, regulatory $\mathrm{T}$ cells, tumor-associated macrophages, antitumor immunity, breast cancer infiltration in tumor tissue when compared to the controls or irradiation alone. Mechanistically, HS-1793 suppressed tumor growth via the activation of effector $\mathrm{T}$ cells in irradiated mice. On the whole, the findings of the present study reveal that HS-1793 treatment improves the outcome of radiation therapy by enhancing antitumor immunity. Indeed, HS-1793 appears to be a good therapeutic candidate for use in combination with radiotherapy in breast cancer.

\section{Introduction}

Breast cancer is the most common malignant tumor affecting women worldwide and its incidence is increasing. However, the overall mortality rate has been reduced by early diagnostic programs and optimized treatment (1). Radiation has been adopted as a standard therapy for breast cancer and external beam radiotherapy is generally used for chest wall and total breast irradiation (2). However, breast cancer is a heterogeneous disease and differs greatly among different patients, and even within each individual tumor (3); thus, radiotherapy sometimes results in unsatisfactory effects in local and regional control for certain subtypes of breast cancer and treatment failure seems to be due to radiation resistance (4).

Radiation is not tumor-specific but can directly kill cancer cells and has thus been used in the treatment of cancer patients (5). However, major drawbacks of radiation therapy are the undesirable effects on normal tissue and the radiation resistance of cancer cells. In particular, radiation can induce lymphocyte damage as conventional radiation fields frequently include hematopoietic bone marrow or large blood volumes. Derangements in lymphocyte function creates an immunosuppressive condition in cancer patients, as radiation increases transforming growth factor (TGF) $-\beta$ secretion and the infiltration of regulatory $\mathrm{T}$ cells (Tregs) into the tumor microenvironment $(6,7)$. These results suggest that radiation may perversely, generate an anticancer immunity that promotes tumor recurrence.

The status of a host's immune response affects both the development and progression of cancer. Cancer cells often acquire immunotolerance during malignancy and contribute to 
the infiltration of immunosuppressive cells in the tumor microenvironment $(8,9)$. Tumor-associated macrophages (TAMs) and Tregs are both well-known immunosuppressive cells in the tumor microenvironment and these cells inhibit the development of an efficient antitumor response by secretion of interleukin (IL)-10 or TGF- $\beta(10,11)$. Previous studies have reported that infiltrating TAMs and Tregs are directly related to the progression of breast cancer $(12,13)$ and TAM or Treg depletion increases effector $\mathrm{T}$ cell activation $(14,15)$. Cancer cells can release molecules that induce TAM differentiation into immunosuppressive forms, such as the M2 type, or recruit Tregs in the tumor microenvironment $(10,11,16)$. Furthermore, ionizing radiation induces the expression of immunosuppressive cytokines, such as TGF- $\beta$ and IL-10, and is associated with the immunotolerance of cancer cells $(17,18)$. Therefore, there is a critical need for the development of novel approaches that can be used clinically to overcome immune suppression within the tumor microenvironment and to enhance the radiation sensitivity of tumor cells.

Resveratrol is found in red wine and is contained in various food components that have known biological activities (19). A number of studies have indicated that resveratrol suppresses the initiation, promotion and progression of a variety of solid tumors (20-22), and increases immune responses in mice by enhancing lymphocyte proliferation and suppressing the population of Tregs (23). It has also been shown to enhance radiation-induced cell death in various cancer cell lines, as well as the radiation sensitivity of tumor cells (24). However, resveratrol has several disadvantages, including its photosensitivity, its metabolic instability and the high doses required for biological activity. Therefore, in a previous study, the authors synthesized new derivatives, including HS-1793, that overcomes some of the drawbacks associated with resveratrol (25). Previous studies by the authors demonstrated that HS-1793 exerted anticancer effects on various cancer cell lines (24-26), enhanced the radiosensitivity of FM3A cells under hypoxic conditions (27) and exhibited radioprotective activity in $\mathrm{CHO}$ cells (28). In particular, HS-1793 has been shown to enhance antitumor immunity by reducing the number of Tregs and M-2 phenotype TAMs, in mammary tumors of mice $(26,29)$.

The present study demonstrates that HS-1793 increases lymphocyte proliferation and inhibits the DNA damage of lymphocytes in irradiated tumor-bearing mice. In addition, is shown to HS-1793 inhibit the infiltration of Tregs and TAMs, and to decrease the secretion of immunosuppressive cytokines, such as IL-10 and TGF- $\beta$. Thus, HS-1793 may increase the effectiveness of radiation through the enhancement of antitumor immunity in a murine breast tumor model. These results may be useful for the understanding of the pharmacological action of HS-1793 in designing a combination therapy utilizing both pharmacology and radiation.

\section{Materials and methods}

Preparation of the resveratrol analogue, HS-1793. To obtain HS-1793, the stilbene double bond present in resveratrol was substituted with a naphthalene ring as described in a previous study (25). The structure of HS-1793 is illustrated in Fig. 1A. A stock solution was made in absolute ethanol at $125 \mathrm{~g} / \mathrm{l}$, and working dilutions were made directly in saline. The control vehicle was saline containing equivalent amounts of ethanol.
Cells and cell culture. The FM3A murine breast cancer cell line originating from the mammary gland of the $\mathrm{C} 3 \mathrm{H} / \mathrm{He}$ mouse was provided by Professor C.D. Kang, Pusan National University College of Medicine. The cells were cultured in RPMI-1640 (Welgene) supplemented with 10\% FBS (Gibco; Thermo Fisher Scientific, Inc.), $100 \mathrm{U} / \mathrm{ml}$ penicillin and $100 \mathrm{U} / \mathrm{ml}$ streptomycin (complete medium) under humidified conditions at $37^{\circ} \mathrm{C}$ and $5 \% \mathrm{CO}_{2}$ in an incubator.

In vitro cell growth assay. FM3A cells $\left(5 \times 10^{3}\right.$ cells per well) were seeded in 96-well plates in RPMI-1640 supplemented with $10 \%$ FBS. The cells were exposed to HS-1793 treatment $(0-10 \mu \mathrm{g} / \mathrm{ml})$ or irradiation (0-16 Gy) with a BioBeam 8000 (Gamma-Service Medical $\mathrm{GmbH}$ ) irradiator at a dose rate of $1.88 \mathrm{~Gy} / \mathrm{min}$ and were cultured for 24 or $48 \mathrm{~h}$. In addition, some cells were treated with $0.25,0.5$, or $1 \mu \mathrm{g} / \mathrm{ml}$ of HS- 1793 for $24 \mathrm{~h}$ prior to $4 \mathrm{~Gy}$ irradiation. To determine cell growth, 3-(4,5-dimethylthiazol-2-yl)-2,5-diphenyltetrazolium bromide (MTT) was added to each well (25 $\mu \mathrm{l} /$ well) after 24 or $48 \mathrm{~h}$ and incubated at $37^{\circ} \mathrm{C}$ for $4 \mathrm{~h}$. The blue dye absorbed by the cells was dissolved in dimethyl sulfoxide (100 $\mu \mathrm{l} /$ well), and the absorbance was measured with a spectrophotometer (Bio-Rad Laboratories, Inc.) at $490 \mathrm{~nm}$. The $\mathrm{IC}_{50}$ values were calculated using GraphPad Prism (Ver. 8; GraphPad Software Inc).

Clonogenic survival assay. The cell survival assay is based on the clonogenicity of cells to divide indefinitely and form colonies $(28,30)$. In brief, the FM3A cells were trypsinized, counted and plated in triplicate per data point into $100 \mathrm{~mm}$ dishes. The cells were treated with HS-1793 $(0.25,0.5$, $1 \mu \mathrm{g} / \mathrm{ml}$ ) and incubated at $37^{\circ} \mathrm{C}$ for $24 \mathrm{~h}$ prior to irradiation $(2,4,6,8$ and $10 \mathrm{~Gy})$. After approximately 14 days, the colonies were fixed with $95 \%$ methanol at room temperature for $30 \mathrm{~min}$, stained with $1 \%$ crystal violet for $10 \mathrm{~min}$ and counted. The plating efficiency (PE) was based on a previously described method (28).

Animal experiments. The animal experiments were ethically approved by the Committee on the Use and Care of Animals of Dong-A University Hospital (DIACUC-10-14) and the Dong Nam Institute of Radiological and Medical Sciences (DIRAMS AEC-2011-003). Female C3H/He mice, 6 weeks of age (20-25 g), were obtained from Central Lab. Animal Inc. Mice were housed under standard laboratory conditions $\left(22 \pm 2^{\circ} \mathrm{C}, 60 \%\right.$ relative humidity, $12 / 12 \mathrm{~h}$ light/dark cycle, and provided with food and water ad libitum), and animal health and behavior were daily monitored. A total of 75 mice were used in 15 experimental groups with 5 mice per group; 4 groups to determine the radiation dose, 6 groups to analyze radiation-induced DNA damage in lymphocytes, and 5 groups to measure tumor growth and lymphocyte function. FM3A cells $\left(2 \times 10^{6}\right.$ cells $\left./ 50 \mu \mathrm{l}\right)$ were inoculated subcutaneously into the right flanks of female $\mathrm{C} 3 \mathrm{H} / \mathrm{He}$ mice to induce tumors. When the tumors grew to a size of approximately $80-125 \mathrm{~mm}^{3}$, the mice were irradiated with a linear accelerator (Elekta Ltd.) at a dose rate of $5 \mathrm{~Gy} / \mathrm{min}$. In the case of HS-1793 treatment $(0.5$ or $1 \mathrm{mg} / \mathrm{kg})$, the mice were intraperitoneally injected $24 \mathrm{~h}$ prior to irradiation and twice a week for 3 weeks after irradiation. The tumor growth of 70 tumor-bearing mice was observed for 30 days after the first treatment and the 
A
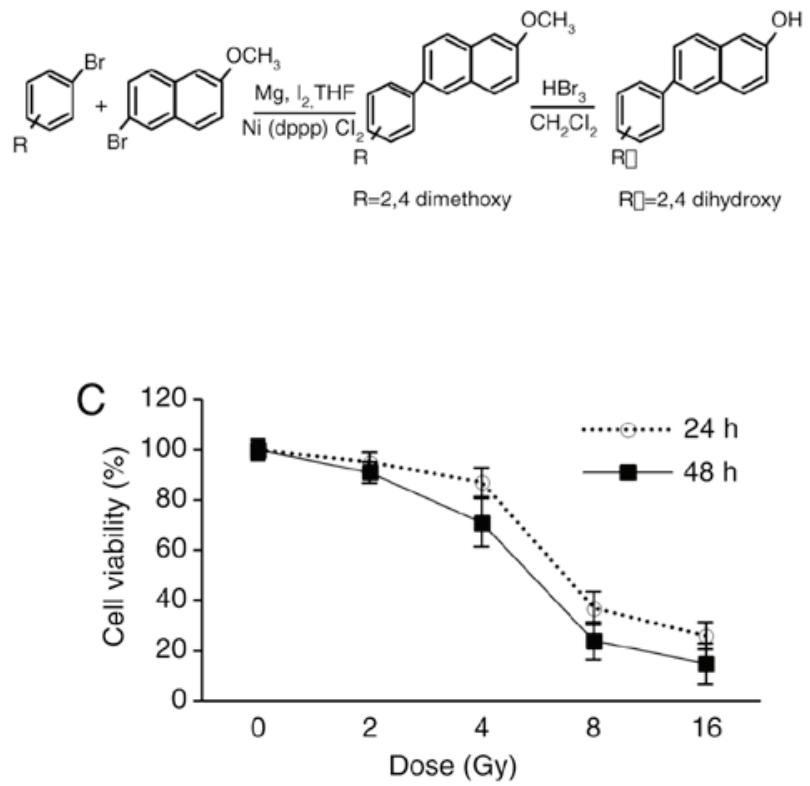

$\mathrm{E}$

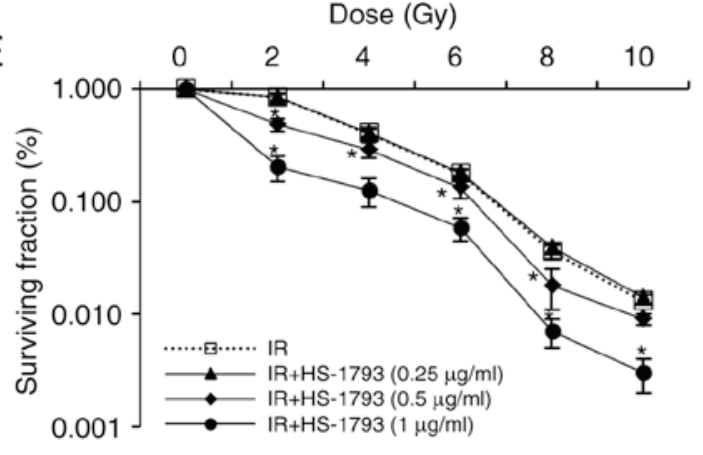

B
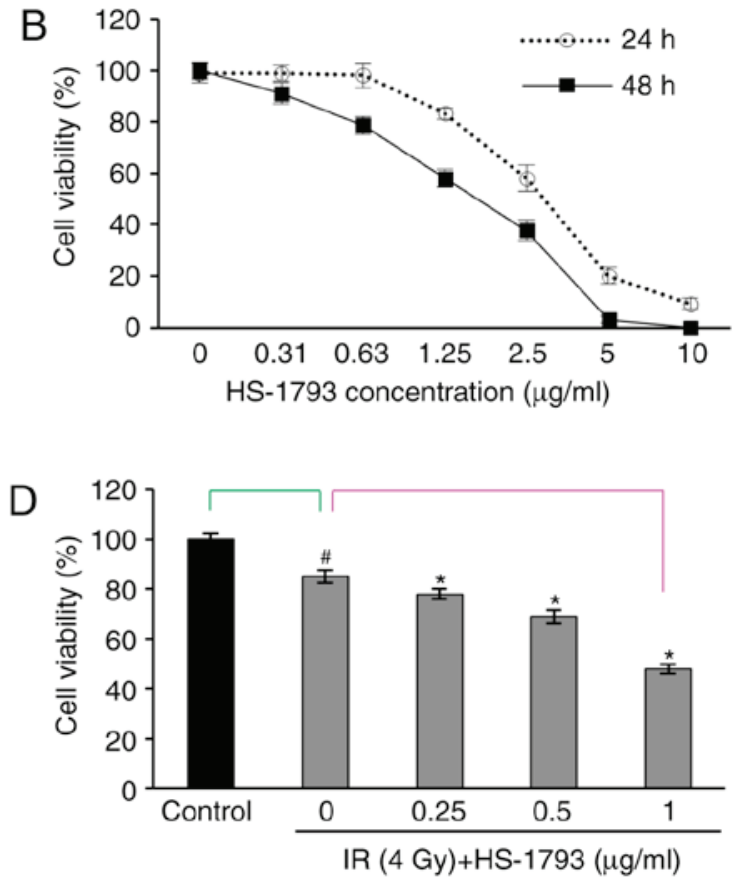

$\mathrm{F}$

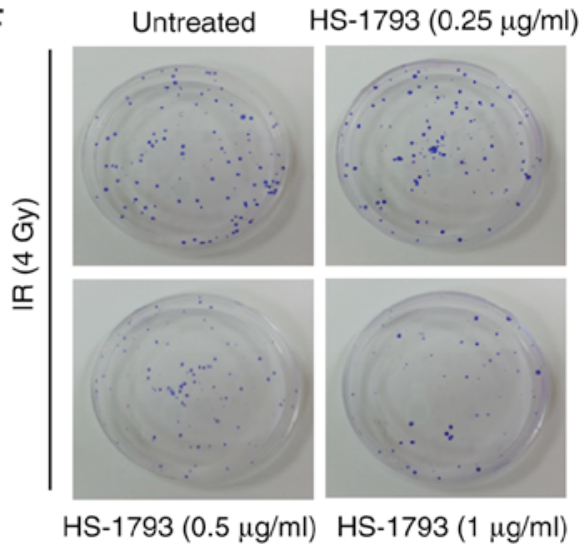

Figure 1. Effect of HS-1793 on the viability in ${ }^{137} \mathrm{Cs} \gamma$-radiation-exposed FM3A cells. (A) Structure of the resveratrol analogue, HS-1793. (B) FM3A cells were treated with the indicated concentrations of HS-1793 $(0.31-10 \mu \mathrm{g} / \mathrm{ml})$ or $(\mathrm{C})$ radiation doses $(0-16 \mathrm{~Gy})$ for 24 and $48 \mathrm{~h}$. (D) FM3A cells were treated with the indicated concentrations of HS-1793 for $24 \mathrm{~h}$ pior to 4 Gy irradiation. The cells were then cultured for $24 \mathrm{~h}$ and cell viability was determined by MTT assay. ${ }^{~} \mathrm{P}<0.05$ as compared with the control and ${ }^{\text {"P }}<0.05$ as compared with irradiation alone (IR); one-way analysis of variance with Tukey's post hoc test. (E) FM3A cells were treated with the indicated concentrations of HS-1793 at $37^{\circ} \mathrm{C}$ for $24 \mathrm{~h}$ prior to irradiation $(2,4,6,8,10 \mathrm{~Gy})$ for clonogenic assays. After approximately 14 days, colonies were counted. Each value in treated cells was calculated with respect to the untreated control. All samples were performed in triplicate and experiments were repeated three times. Results are expressed as percentages of control, and data are the means \pm standard deviations of 3 independent experiments. "P<0.05 as compared with irradiation alone (IR); one-way analysis of variance with Dunnett's post hoc test. (F) Representative images of clonogenic assays showing that radiation inhibited the colony forming capacity of cancer cells in a dose-dependent manner and that HS-1793 enhanced the tumor suppressive effect of radiation.

mice were euthanized by using the $\mathrm{CO}_{2}$ method $(20 \%$ of the chamber volume was displaced per min by the flow rate of $\mathrm{CO}_{2}$ ). Tumor volume was calculated using the following equation: Volume $=W_{i d t h}{ }^{2} \times$ length $\times 0.52$. Additional humane endpoints included a tumor burden that exceeded $20 \mathrm{~mm}$ in any one dimension; tumors that became ulcerated, necrotic or infected; and tumors that interfered with eating or impaired ambulation. The volume of the largest tumor was $3,935 \mathrm{~mm}^{3}$ and the largest diameter of a single tumor was $19.8 \mathrm{~mm}$. None of the animals developed multiple tumors and none were found dead. After sacrificing the tumor-bearing mice, the splenocytes were prepared from an aseptically removed spleen, and paraffin-embedded sections (4- $\mu \mathrm{m}$-thick) were prepared from tumor tissue.
Lymphocyte proliferation assay. Lymphocyte proliferation was determined by 5-bromo-2-deoxyuridine (BrdU) incorporation assay using a cell suspension at $5 \times 10^{5}$ cells/well in flat-bottom 96-well microculture plates. The isolated lymphocytes from tumor-bearing mice were cultured for $48 \mathrm{~h}$ with concanavalin A (Con A; $5 \mu \mathrm{g} / \mathrm{m}$; Sigma-Aldrich; Merck KGaA) and further incubated for $24 \mathrm{~h}$ in the presence of $10 \mu \mathrm{l}$ of the BrdU solution in RPMI medium (1:100 diluent). BrdU incorporation was measured using a Cell Proliferation ELISA BrdU kit (Roche Diagnosis $\mathrm{GmbH}$ ) following the supplier's specifications.

Comet assay. The mouse spleens were aseptically removed, and a single-cell suspension was prepared by gently teasing 
the cells through a sterile stainless-steel screen. After removing red blood cells, the splenocytes were suspended in PBS. The dye exclusion test was used to determine the number of viable cells present in a cell suspension. Equal parts of $0.4 \%$ Trypan blue dye and the cell suspension was mixed, loaded to a hemocytometer, and examined immediately under a optical microscope (Olympus Corp.). The viable cell density was adjusted to $1-2 \times 10^{5} / \mathrm{ml}$ and stored at $4^{\circ} \mathrm{C}$. The lymphocytes were mixed with low melting point agarose at $37^{\circ} \mathrm{C}$. The comet assay was performed as previously described (28). In brief, this mixture was placed on top of a layer of $0.5 \%$ normal melting point agarose on a slide covered with a coverslip, and then incubated at $4^{\circ} \mathrm{C}$ until solid. The slide was placed in chilled lysis buffer (100 mM EDTA, 2.5 M sodium chloride, $10 \mathrm{mM}$ Trizma base and $1 \% \mathrm{~N}$-lauroylsarcosinate, adjusted to $\mathrm{pH} 10.0$, with $1 \%$ Triton X-100) and unwinding buffer (1 mM EDTA and $300 \mathrm{mM}$ sodium hydroxide, $\mathrm{pH}>13$ ), respectively, and subjected to electrophoresis. All slides were gently washed with 0.4 M Tris buffer, stained with Gel green DNA dye (Biotium, Inc.) and analyzed under a fluorescence microscope (Carl Zeiss Microscopy $\mathrm{GmbH}$ ). The images were captured, and a minimum of 100 comets per slide, in triplicate for a group, were analyzed using Metafer 4 software (Carl Zeiss GmbH), which yields \% DNA in the tail, tail length, tail moment (TM) and olive moment (OM) directly. The parameter TM is the product of tail length and \% DNA in the tail, and the olive moment is the product of the distance between the center of the head and the center of the tail and \% DNA in the tail (30).

Flow cytometric analysis. Lymphocyte subpopulations among splenocytes were analyzed with a flow cytometer (Beckman Coulter, Inc.) following standard surface staining procedures using the appropriately diluted antibodies as follows: PE-conjugated anti-mouse CD4 (1:100, cat. no. 553730, BD Biosciences), FITC-conjugated anti-mouse CD8a (1:100, cat. no. 553031, BD Biosciences), PE/Cy7-conjugated anti-mouse CD25 (1:100, cat. no. 60-0251, Tonbo Biosciences) and isotype control antibodies (1:100, cat. no. 553989, cat. no. 553929, BD Biosciences; cat. no. 60-430, cat. no. 35-4714, Tonbo Biosciences) (the cells were incubated with the antibodies at $4^{\circ} \mathrm{C}$ for $30 \mathrm{~min}$ ). For the confirmation of FoxP3-expressing Tregs and interferon (IFN)- $\gamma$-expressing $\mathrm{CD}^{+} \mathrm{T}$ cells, standard surface staining procedures were combined with an intracellular staining method using FITC-conjugated anti-mouse FoxP3 (1:100, cat. no. 35-5773, Tonbo Biosciences) and PE/Cy7-conjugated anti-mouse IFN- $\gamma$ (1:100, cat. no. 561040, BD Biosciences) antibodies, respectively. For the intracellular FoxP3 and IFN- $\gamma$ titration, the cells were pre-incubated with Protein Transport Inhibitor containing Monensin (BD Biosciences) at $37^{\circ} \mathrm{C}$ for $6 \mathrm{~h}$ prior to harvesting the cells. Quantification was performed by FACS analysis using a Beckman Coulter FC500 (Beckman Coulter, Inc.).

Enzyme-linked immune absorbent spot (ELISpot) assay. ImmunoSpot plates (Merck Millipore) were washed with 35\% ethanol at room temperature for $1 \mathrm{~min}$, coated with anti-mouse IFN- $\gamma$ antibody (1:100, cat. no. 551881, BD Biosciences) dissolved in PBS at $4^{\circ} \mathrm{C}$ overnight, and blocked with BSA $\left(10 \mathrm{~g} / 1\right.$ in PBS) for $1 \mathrm{~h}$. Splenocytes $\left(5 \times 10^{4}\right.$ cells/well) from each mouse were seeded and incubated with stimulant cocktail and $\mathrm{HS}-1793$ at $37^{\circ} \mathrm{C}$ for $24 \mathrm{~h}$. The plate was treated with biotinylated detection antibody at room temperature for $2 \mathrm{~h}$ and streptavidin-HRP (100 $\mu \mathrm{l} /$ well) at room temperature for $2 \mathrm{~h}$. After washing the plate, a chromogenic substrate and $\mathrm{H}_{2} \mathrm{O}_{2}$ were added to each well to produce spots. The numbers of spots were analyzed using the AID ELISpot Reader System (Autoimmun Diagnostika GmbH).

Cytotoxicity assay. Splenocytes $\left(3 \times 10^{7}\right.$ cells $\left./ 5 \mathrm{ml}\right)$ were re-stimulated with mitomycin C $(10 \mu \mathrm{g} / \mathrm{ml})$ for $20 \mathrm{~min}$ and washed with PBS. The re-stimulated splenocytes (effector cells) were incubated with target cells $\left(2 \times 10^{4} \mathrm{FM} 3 \mathrm{~A}\right.$ cells) at various effector/target ratios (10:1, 25:1 and 50:1) in 96-well round-bottom microplates $(200 \mu \mathrm{l})$ for 3 days. Following centrifugation, at room temperature for $10 \mathrm{~min}, 100 \mu \mathrm{l}$ of supernatants were collected, and the lactate dehydrogenase (LDH) released from the target cells was measured with an LDH release assaying kit (Roche Applied Science) according to the manufacturer's instructions. Percentage cytotoxicity was calculated by the following formula: $\%$ Cytotoxicity= $\left(\mathrm{OD}_{\text {experiment }}-\mathrm{OD}_{\text {effector spontaneous }}-\mathrm{OD}_{\text {target spontaneous }}\right) / \mathrm{OD}_{\text {target maximum }}{ }^{-}$ $\mathrm{OD}_{\text {target spontaneous }} \mathrm{x} 100$.

The $\mathrm{OD}_{\text {spontaneous }}$ amount of effector and target cells was controlled by separate incubations of the respective populations. $\mathrm{OD}_{\text {maximum }}$ was measured after lysis of the target cells with $2 \%$ Triton X-100.

Histopathological analysis. Tumor-infiltrating TAMs and Tregs were evaluated by immunofluorescent staining of deparaffinized sections $(5-\mu \mathrm{m}$-thick) and the tissue sections were incubated at $4^{\circ} \mathrm{C}$ with PE-conjugated anti-mouse CD25 (1:100, cat. no. 553866; BD Biosciences) or CD206 (1:100, cat. no. 141706; BioLegend), FITC-conjugated anti-mouse IFN- $\gamma$ antibodies (1:100, cat. no. ab21039; Abcam) for overnight. Counterstaining was performed with VECTASHIELD Antifade Mounting Medium with DAPI (Vector Laboratories). The slides were observed and photographed on a Carl Zeiss LSM 700 confocal microscope and processed by ZEN 2009 (Carl Zeiss Microscopy GmbH).

Cytokine production assay. Splenocytes were cultured with Con A $(5 \mu \mathrm{g} / \mathrm{ml})$ for $24 \mathrm{~h}$ at $10^{7}$ cells $/ \mathrm{ml}$ in serum-free RPMI medium containing $200 \mu \mathrm{g} / \mathrm{ml}$ BSA. The IL-4, IL-10, TGF- $\beta$ and IFN- $\gamma$ concentrations in the culture supernatants of the splenocytes were determined with ELISA kits (BD Biosciences) according to the manufacturer's instructions.

Statistical analysis. Results are expressed as the means \pm standard deviation (SD). Statistical significance was tested using the Statistical Package for the Social Sciences statistical software for Windows, Ver. 18.0 (SPSS Inc.). Significant differences were evaluated by one-way analysis of variance for multiple comparisons. Tukey's post hoc test was used to compare several groups with different controls, and Dunnett's post hoc test was used to compare all other samples with a single control. $\mathrm{P}<0.05$ was considered to indicate a statistically significant difference.

\section{Results}

HS-1793 enhances the radiation-induced death pf FM3A cells. The effect of HS-1793 on radiation-induced death of 
murine breast cancer cells was investigated and the viability of FM3A cells was measured by MTT assay at various HS-1793 concentrations and/or radiation doses. HS-1793 inhibited cell growth in a dose-dependent manner and the $\mathrm{IC}_{50}$ value was $1.9 \mu \mathrm{g} / \mathrm{ml}$ at $48 \mathrm{~h}$ (Fig. 1B). The survival curve of gamma-radiation was generated for the FM3A cells (Fig. 1C) and a gamma-radiation dose of $4 \mathrm{~Gy}$, which yielded $29 \%$ growth inhibition, was selected for use in combination with HS-1793. To determine whether HS-1793 can enhance the sensitivity of the FM3A cells to radiation-induced cell death, the cells were plated for MTT assay and clonogenic cell survival assay. As shown Fig. 1D, HS-1793 treatment exerted a significant growth inhibitory effect on the 4 Gy-exposed FM3A cells in a dose-dependent manner. In addition, the colony formation assays with HS-1793 reduced the plating efficiency of the FM3A cells and sensitized the FM3A cells to radiation treatment at 0.5 and $1 \mu \mathrm{g} / \mathrm{ml}$ (Fig. $1 \mathrm{E}$ and F). These results suggest that HS-1793 can enhance radiation induced cell death of murine breast cancer cells.

HS-1793 induces lymphocyte proliferation by decreasing radiation-induced DNA damage in irradiated tumor-bearing mice. Lymphocytes are known to be very radiosensitive as radiation causes DNA cross-linkage and cells undergo cell death rapidly, with some cells being affected within $24 \mathrm{~h}$ of irradiation (31). A previous study by the authors demonstrated that HS-1793 induced radioprotective effects through free radical scavenging and that this activity inhibited cellular DNA damage (28). The present study therefore examined whether a similar pattern of results could be obtained with the FM3A cell line, which can be used for animal experiments. A gamma-radiation dose of 4 Gy, exhibited an $18 \%$ growth inhibition, and was selected as the dose for use in combination with HS-1793 (Fig. 2B). The protective effects of HS-1793 on lymphocyte proliferation in the 4 Gy-irradiated tumor-bearing mice were then investigated. The results revealed that HS-1793 did not directly induce lymphocyte proliferation in tumor-bearing mice with or without Con A stimulation. Gamma radiation induced a reduction in lymphocyte proliferation, whereas combination treatment with HS-1793 prevented the decrease in radiation-induced lymphocyte proliferation in the presence or absence of Con A in tumor-bearing mice (Fig. 3A). Subsequently, whether HS-1793 treatment inhibits radiation-induced DNA damage in lymphocytes of tumor-bearing mice was examined by comet assays to measure DNA breakage. The lymphocytes were isolated from the spleens of tumor-bearing mice following irradiation at $24 \mathrm{~h}$ and the DNA damage of lymphocytes was analyzed by comet assay. No significant differences were observed between the control and HS-1793 alone groups, whereas the 4 Gy-irradiated lymphocytes exhibited an increased DNA damage in comet parameters, such as \% DNA in tail, tail length, tail moment and olive moment. However, HS-1793 treatment inhibited the radiation-induced DNA damage of lymphocytes from the tumor-bearing mice (Fig. 3B and C). These data suggest that HS-1793 treatment increases lymphocyte proliferation by inhibiting DNA damage.

HS-1793 inhibits the induction of Tregs in irradiated tumor-bearing mice. To examine whether HS-1793 can modulate the production of IL-4 for T cell development and
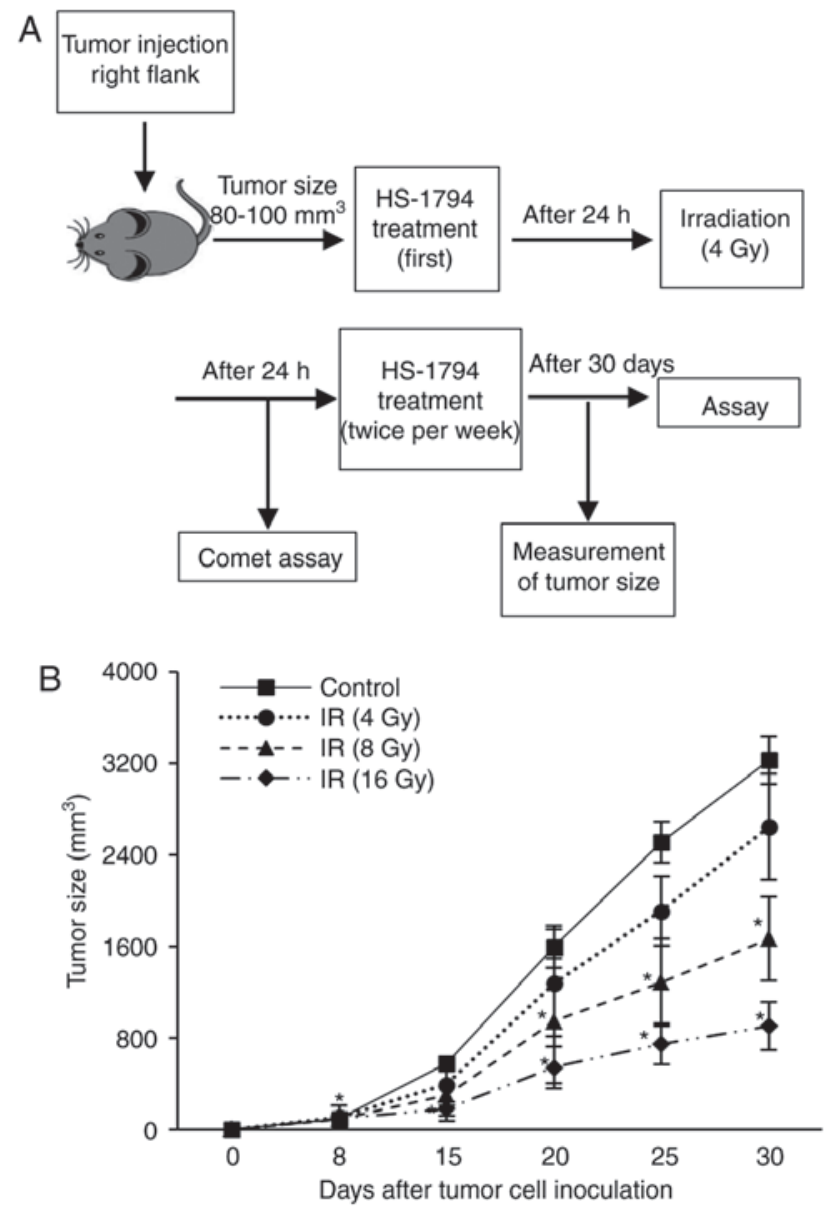

Figure 2. Optimal dose of radiation for combined treatment of HS-1793 in tumor-bearing mice. (A) Schematic diagram showing the schedule of combination treatments in FM3A tumor-bearing mice. (B) For the evaluation of the optimal dose of radiation for combination treatment with HS-1793, FM3A cells $\left(2 \times 10^{6}\right.$ cells $\left./ 50 \mu 1\right)$ were inoculated subcutaneously into the right flanks of female $\mathrm{C} 3 \mathrm{H} / \mathrm{He}$ mice. When the tumor grew to a size of approximately $80-125 \mathrm{~mm}^{3}$, the mice were irradiated with various doses (4, 8 and $\left.16 \mathrm{~Gy}\right)$ and tumor size was assessed once a week for 30 days. Data reported as the mean tumor size $\pm \mathrm{SD}$ of 5 mice per group. ${ }^{*} \mathrm{P}<0.05$ as compared with the control; one-way analysis of variance with Dunnett's post hoc test.

immune suppressive cytokines, such as IL-10 and TGF- $\beta$ by radiation treatment, the levels of cytokines in the cultured supernatants of Con A-stimulated lymphocytes were measured. As shown Fig. 4A, HS-1793 treatment increased IL-4 production; however, this increase was reduced by radiation treatment in the tumor-bearing mice. The administration of HS-1793 significantly enhanced IL-4 secretion in the irradiated tumor-bearing mice. IL-10 and TGF- $\beta$ are important factors involved in Treg induction $(11,32)$. Therefore, whether HS-1793 modulates the induction of Tregs by the regulation of IL-10 and TGF- $\beta$ production in irradiated tumor-bearing mice was investigated. HS-1793 treatment inhibited the secretion of IL-10 and TGF- $\beta$ in both the control and irradiated tumor-bearing mice, whereas irradiation efficiently increased the secretion of both IL-10 and TGF- $\beta$ in the tumor-bearing mice not exposed to the compound (Fig. 4A). It is possible that radiation induced Tregs, resulting in the enhanced production of IL-10 and TGF- $\beta$. The proportion of Treg markers (FoxP $3{ }^{+} \mathrm{CD} 25^{+}$) among $\mathrm{CD}^{+} \mathrm{T}$ cells was determined by flow cytometric 

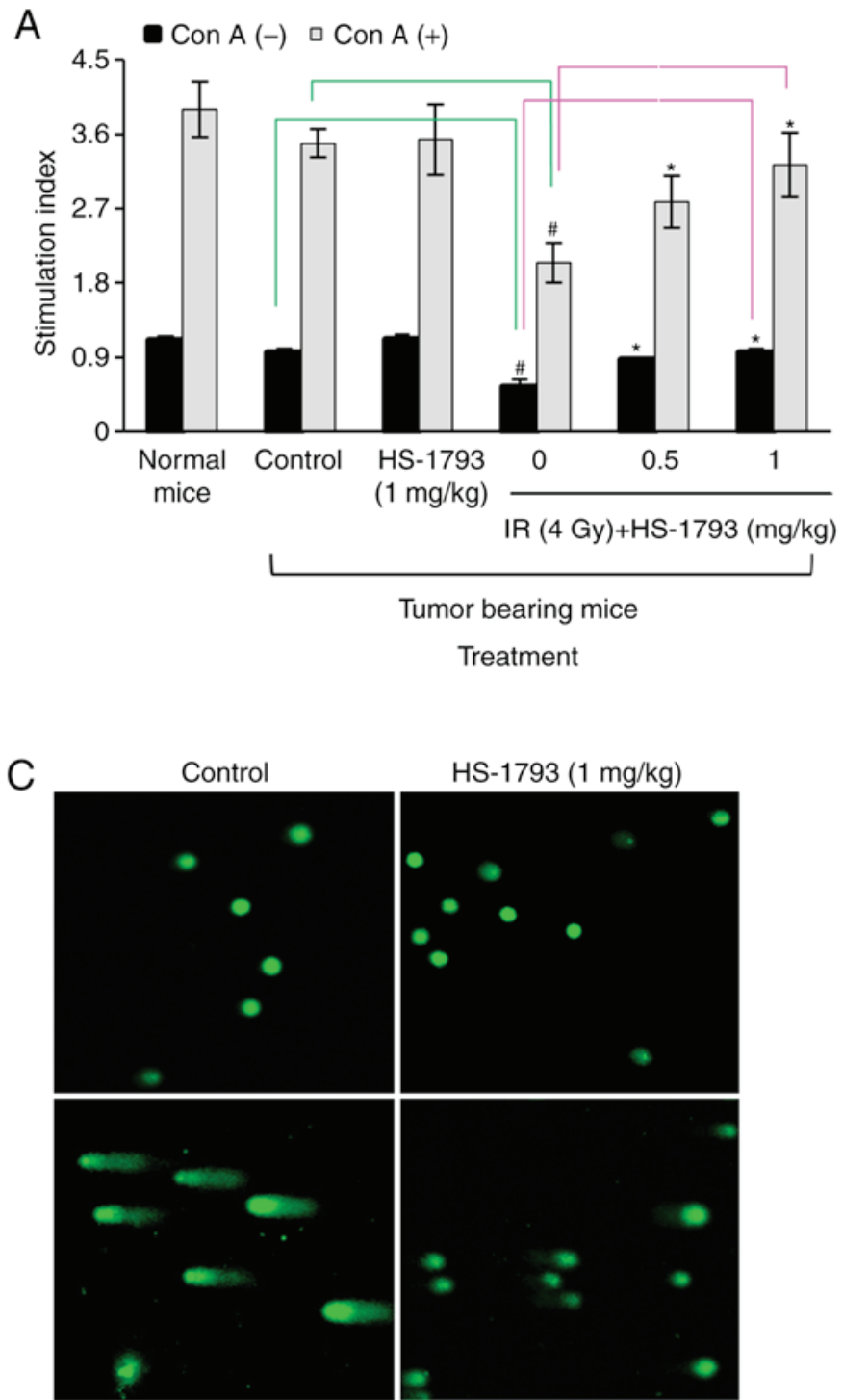

IR (4 Gy)

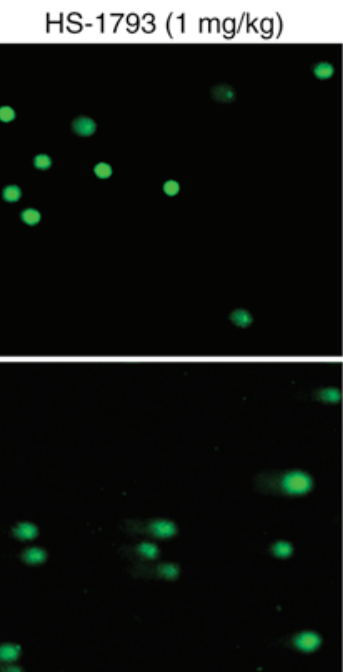

IR+HS-1793 (1 mg/kg)
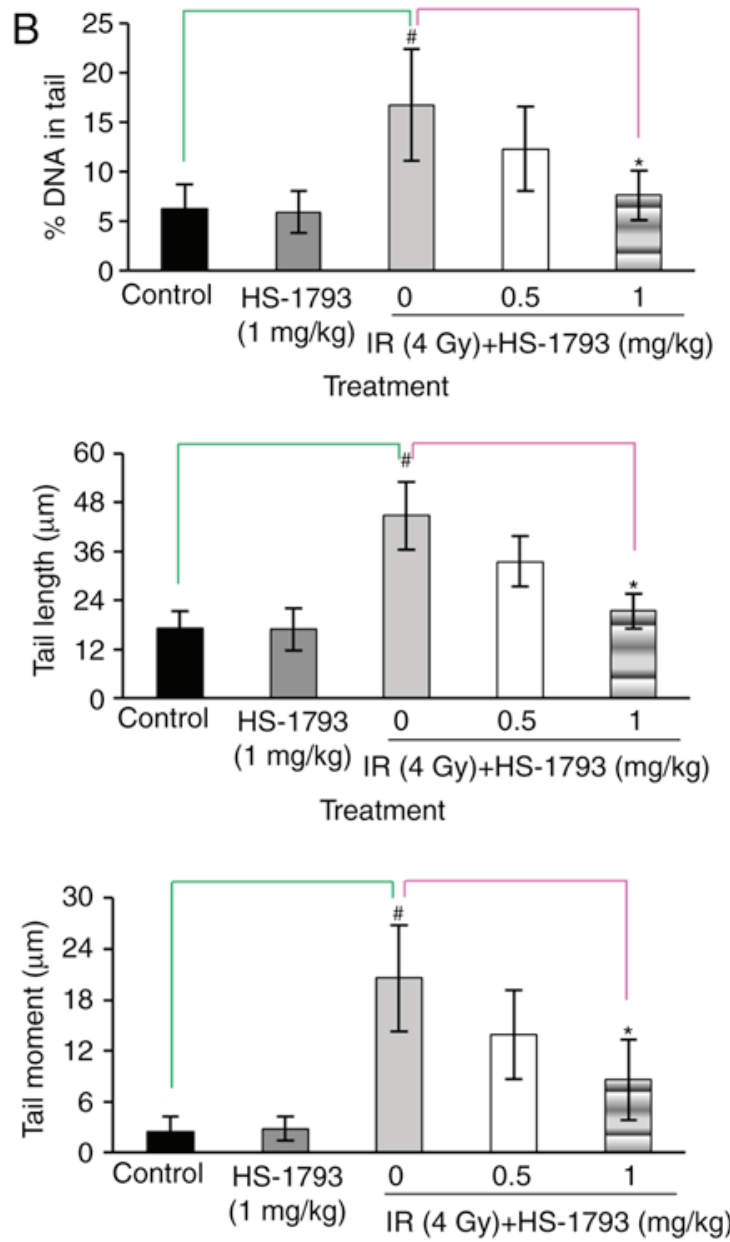

Treatment

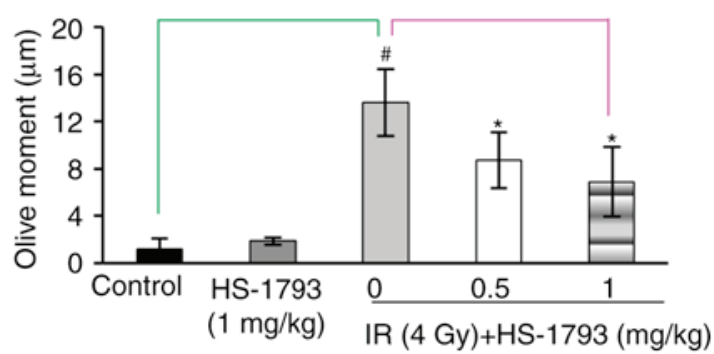

Treatment

Figure 3. Effect of HS-1793 on the proliferation and DNA damage of radiation induced lymphocytes in tumor-bearing mice. FM3A cells $\left(2 \times 10^{6}\right.$ cells $\left./ 50 \mu 1\right)$ were inoculated subcutaneously into the right flanks of female $\mathrm{C} 3 \mathrm{H} / \mathrm{He}$ mice. At a tumor size of approximately $80-100 \mathrm{~mm}^{3}$, the mice were treated with intraperitoneal injections of HS-1793 $(0.5$ and $1 \mathrm{mg} / \mathrm{kg})$ and were irradiated with $4 \mathrm{~Gy}$. After $24 \mathrm{~h}$, the mice were treated with HS-1793 twice a week for 3 weeks. (A) Con A-stimulated lymphocyte proliferation assay was performed with splenocytes isolated from each group at 3 weeks after the HS-1793 injection, and proliferation was measured on day 3 by the incorporation of BrdU during the final $24 \mathrm{~h}$. (B) Comet assays were performed with splenocytes isolated from each group at $24 \mathrm{~h}$ after irradiation. The representative comet parameters (\% DNA in tail, tail length, tail moment, and olive tail moment) and (C) the photomicrographs of comet length are presented for each condition. A minimum of 100 cells were analyzed using Metafer 4 software. Data reported as the means \pm SD from 5 mice per group. ${ }^{*} \mathrm{P}<0.05$ as compared with the control and ${ }^{*} \mathrm{P}<0.05$ as compared with irradiation alone (IR); one-way analysis of variance with Tukey's post hoc test.

analysis in all mice. The cell ratio of $\mathrm{FoxP} 3{ }^{+} \mathrm{CD} 25^{+}$to $\mathrm{CD} 4^{+}$cells exhibited some differences between the control and irradiated tumor-bearing mice groups, and irradiation increased the proportion of Tregs in the tumor-bearing mice. By contrast, HS-1793 treatment significantly decreased the population of $\mathrm{FoxP}^{+} \mathrm{CD} 25^{+}$cells among $\mathrm{CD} 4{ }^{+}$cells in irradiated tumor-bearing mice (Fig. 4B). This confirmed that HS-1793 treatment reduced the infiltration of Tregs in tumor tissue following irradiation (Fig. 4C).
$H S-1793$ increases the amount of IFN- $\gamma$-expressing $C D 8^{+}$ $T$ cells in irradiated tumor-bearing mice. The authors have previously demonstrated that HS-1793 significantly increased IFN- $\gamma$ secretion in the cultured supernatants of splenocytes and tumor tissue of tumor-bearing mice (26). Therefore, the present study investigated whether HS-1793 treatment can enhance effector $\mathrm{T}$ cells involved in the antitumor immunity of irradiated tumor-bearing mice. The frequency of $\mathrm{CD} 8^{+} \mathrm{T}$ cells was reduced in the irradiated tumor-bearing mice, but 
A

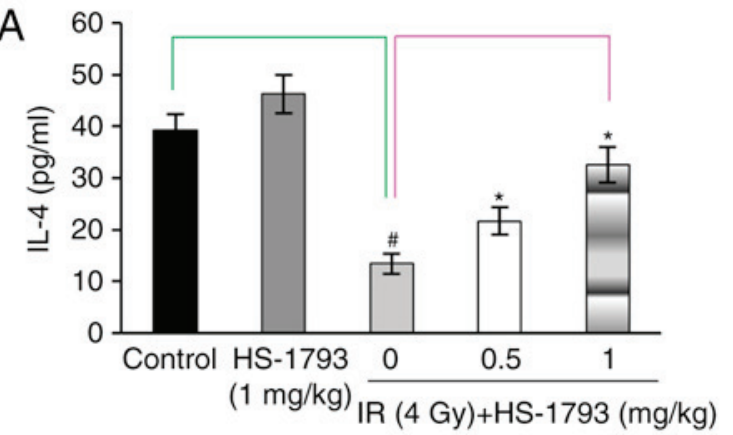

Treatment

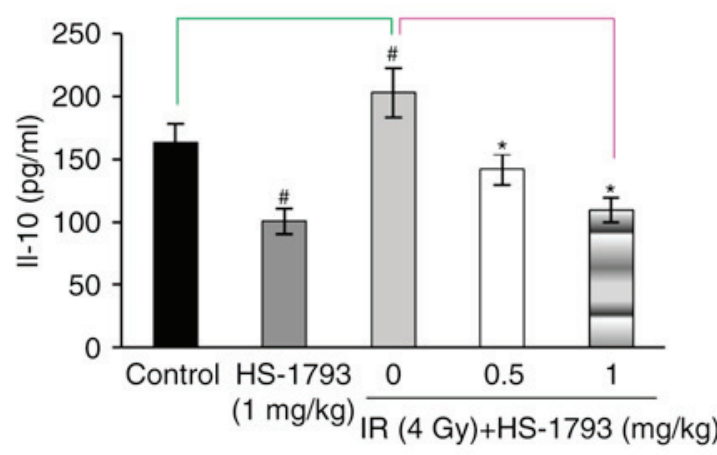

Treatment

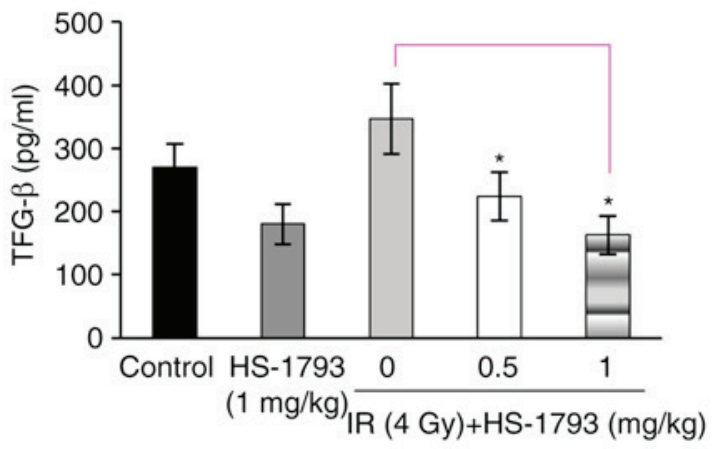

Treatment

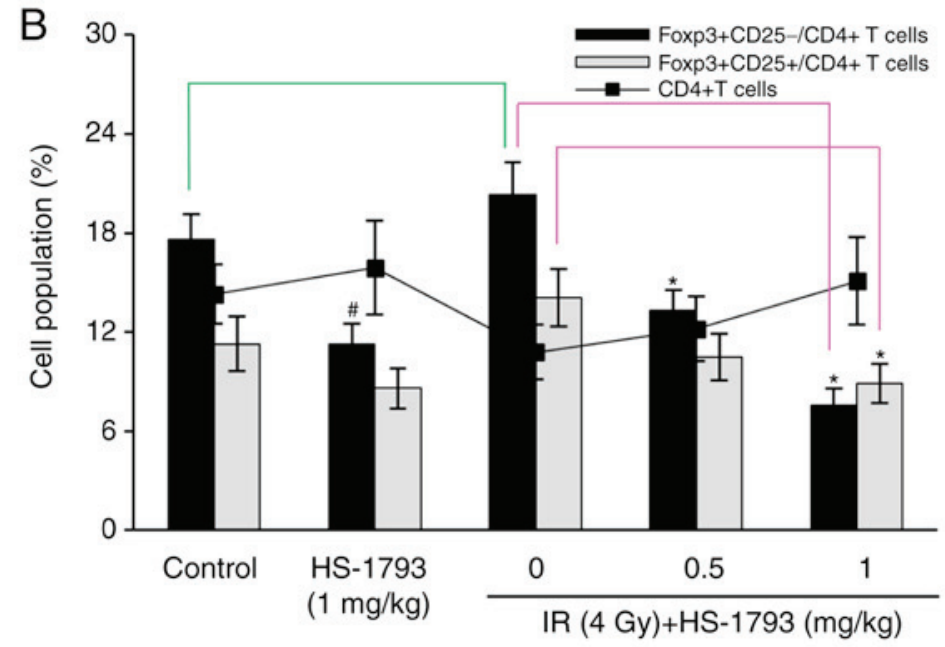

Treatment

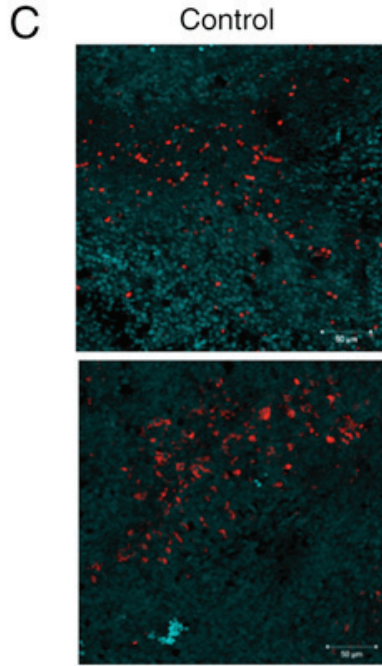

IR (4 Gy)
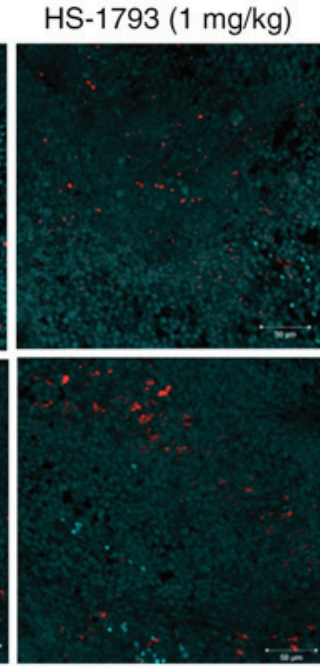

IR+HS-1793 (1 mg/kg)

Figure 4. Effect of HS-1793 on Tregs of irradiated tumor-bearing mice. After the final injections of HS-1793, splenocytes from aseptically removed spleen and paraffin-embedded sections of tumor tissue were prepared. (A) Splenocytes were cultured with concanavalin A (5 $\mu \mathrm{g} / \mathrm{ml})$ for $24 \mathrm{~h}$ and the cultured supernatants were analyzed for cytokine concentrations by ELISA. (B) Splenocytes were analyzed for the expression of CD4, CD25 and intracellular FoxP3 by flow cytometry. The percent gated cells of FoxP3 ${ }^{+} \mathrm{CD} 25^{+}$cells among CD4 ${ }^{+} \mathrm{T}$ cells is shown. (C) Immunofluorescence staining (x400) for CD25 $5^{+} \mathrm{T}$ cell infiltration in tumor tissue. Data reported as the means \pm SD from 5 mice per group. ${ }^{\#} \mathrm{P}<0.05$ as compared with the control and ${ }^{*} \mathrm{P}<0.05$ as compared with irradiation alone (IR); one-way analysis of variance with Tukey's post hoc test.

was prominently recovered in tne HS-1793-treated mice in comparison with the control tumor-bearing mice (Fig. 5A). In addition, the results from assays of IFN- $\gamma$ secretion evaluated by ELISpot and ELISA were consistent with the frequency of $\mathrm{CD}^{+} \mathrm{T}$ cells observed (Fig. 5B and C).

HS-1793 inhibits the infiltration of TAMs in tumor tissue of irradiated tumor-bearing mice via upregulation of IFN- $\gamma$. It has been previously reported that HS-1793 treatment increases IFN- $\gamma$ expression and suppresses TAM infiltration in tumor tissues compared to control mice (29). Therefore, the present study whether the HS-1793-induced IFN- $\gamma$ secretion inhibited TAM infiltration in tumor tissue following radiation treatment. The distribution of CD206 ${ }^{+}$TAMs in irradiated tumor tissue was similar compared to that of the control tumor tissue. By contrast, treatment with HS-1793 suppressed the infiltration of CD206 ${ }^{+}$TAMs both in the control tumor-bearing mice and in the irradiated tumor-bearing mice. These results are consistent with the IFN- $\gamma$ expression observed in the tumor tissue (Fig. 6). Taken together, these results suggest that HS-1793 may overcome TAM-induced immunosuppression by modulating IFN- $\gamma$ secretion, although radiation elicits a number of changes in the tumor microenvironment that are unfavorable for the induction of antitumor immunity.

HS-1793 significantly enhances the effect of radiotherapy on tumor growth via the induction of antitumor immunity. Although the HS-1793 injections did not completely remove the established tumors and protect against tumor formation, HS-1793 did reduce tumor growth and attenuated tumor formation in a previous study by the authors (26). Therefore, in the present study, whether HS-1793 and radiation can enhance the antitumor effects in 
A
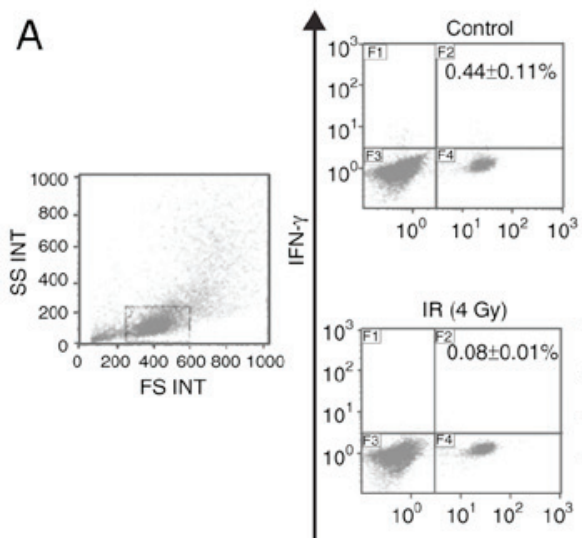

\section{B}

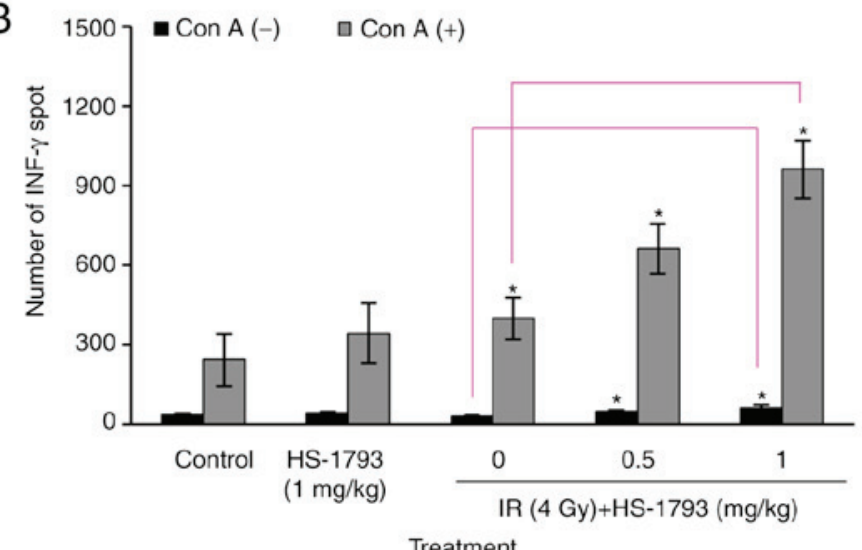

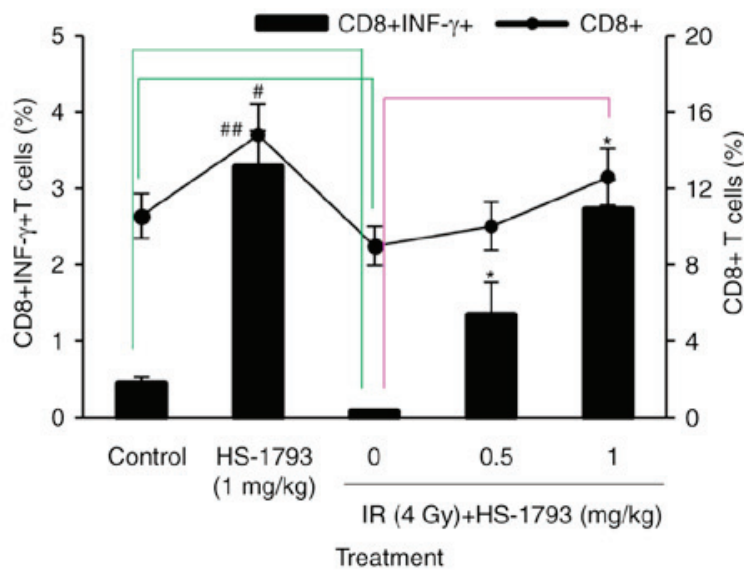

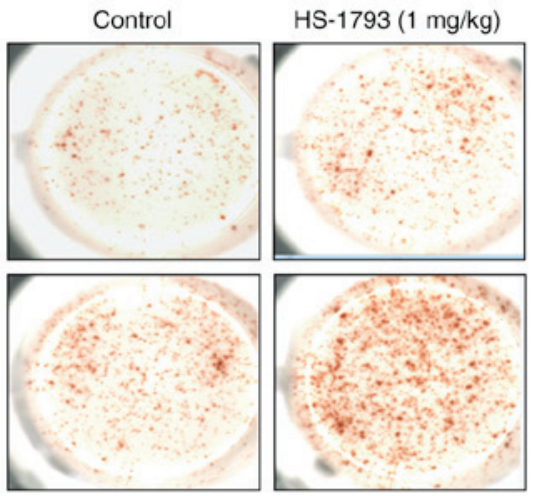

IR (4 Gy)

IR + HS-1793 (1 mg/kg)

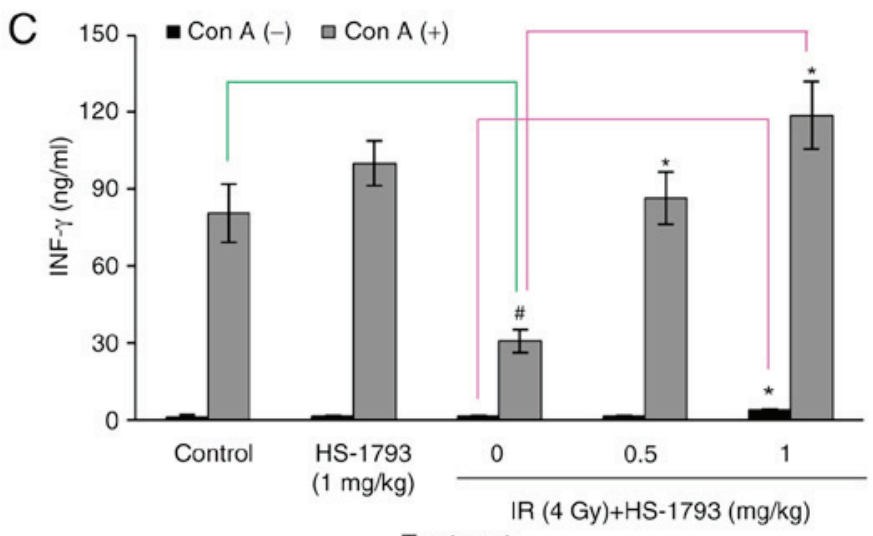

Treatment

Figure 5. Effect of HS-1793 on IFN- $\gamma$ expressing $\mathrm{CD}^{+} \mathrm{T}$ cells of irradiated tumor-bearing mice. After the final injections of HS-1793, splenocytes were analyzed for the expression of CD8 and intracellular IFN- $\gamma$ by flow cytometer and ELISPOT assay. (A) Percentage gated cells of CD8 $8^{+} \mathrm{T}$ cells and IFN- $\gamma$ producing $\mathrm{CD}^{+} \mathrm{T}$ cells were calculated. (B) Splenocytes $\left(5 \times 10^{4}\right.$ cells/well) were seeded in ImmunoSpot plates coated with anti-mouse IFN- $\gamma$ antibody and incubated with stimulant cocktail. ImmunoSpot assay used to show the number of spot and the representative images in each condition. (C) Splenocytes were cultured with concanavalin A $(5 \mu \mathrm{g} / \mathrm{ml})$ for $24 \mathrm{~h}$ and the amounts of IFN- $\gamma$ in culture supernatants were determined by ELISA. Data reported as the means \pm SD from 5 mice per group. ${ }^{\#} \mathrm{P}<0.05$ or ${ }^{\# \#} \mathrm{P}<0.05$ as compared with the control and ${ }^{*} \mathrm{P}<0.05$ as compared with irradiation alone (IR); one-way analysis of variance with Tukey's post hoc test.

tumor-bearing mice compared to radiation alone was investigated. Cytotoxicity assays were performed for the tumor-specific lysis activity of effector T cells following combination treatment. As shown in Fig. 7A, HS-1793 induced an increase in cytotoxicity compared with the control or irradiation alone at all E:T ratios, and also enhanced the cytotoxicity of target FM3A cells in irradiated tumor-bearing mice. Furthermore, the therapeutic efficacy of HS-1793 in reducing tumor size following radiotherapy was observed. The $\mathrm{C} 3 \mathrm{H} / \mathrm{He}$ mice were intraperitoneally injected with HS-1793 (0.5 and $1 \mathrm{mg} / \mathrm{kg})$ twice a week for 3 weeks in the control or irradiated tumor-bearing mice, for the evaluation of the therapeutic antitumor effects (Fig. 2A). Irradiation inhibited the tumor growth of the FM3A cells in a dose-dependent manner and the dose for treatment was $4 \mathrm{~Gy}$, which exerted a $23 \%$ inhibition (Fig. 7B). In addition, treatment with HS-1793 $(1 \mathrm{mg} / \mathrm{kg}$ ) alone produced a $44 \%$ inhibition of tumor growth in 

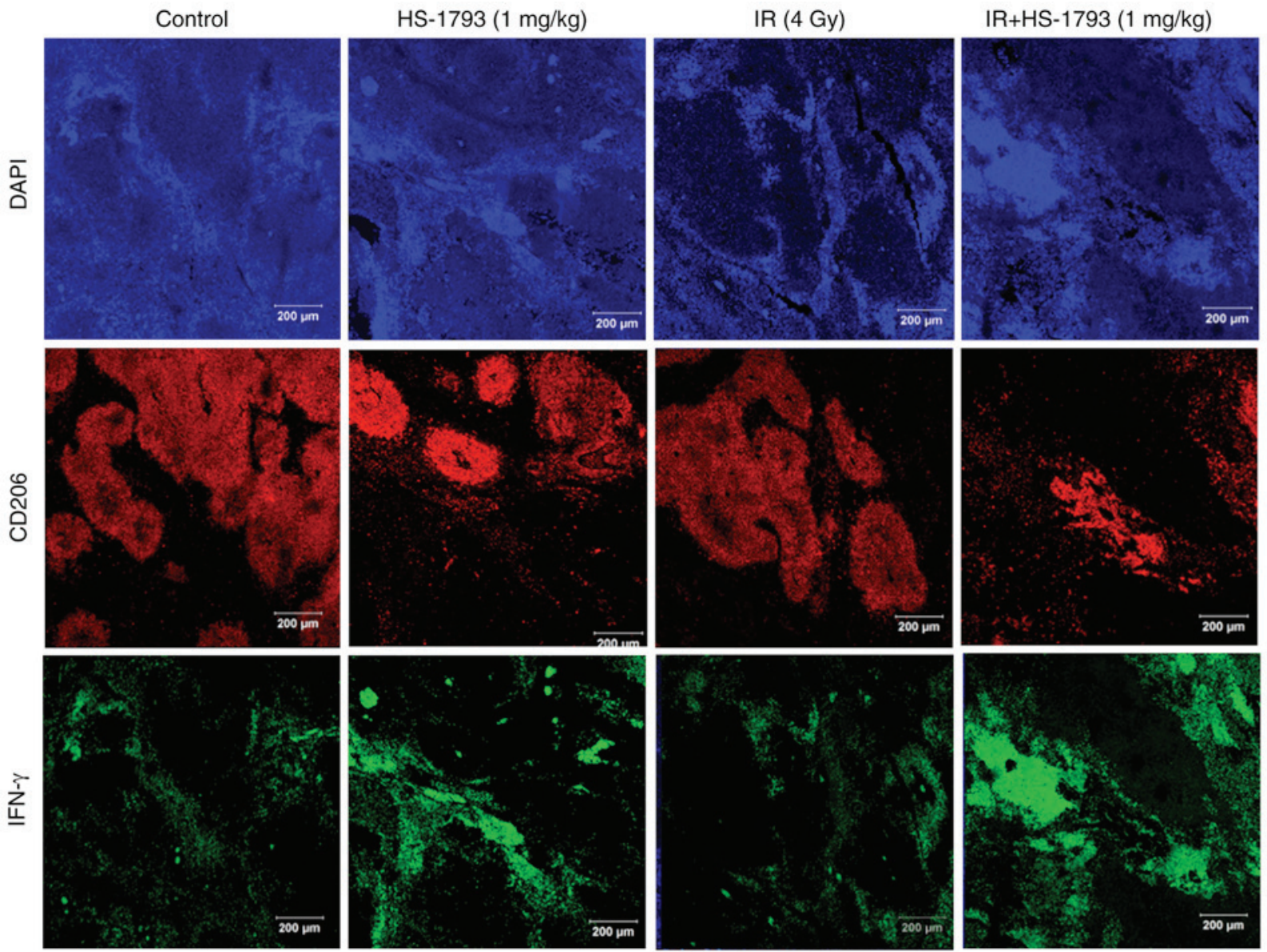

Figure 6. Effect of HS-1793 on infiltration of tumor-associated macrophages (TAMs) in irradiated tumor-bearing mice. Paraffin-embedded sections (5- $\mu \mathrm{m}$-thick) were prepared from tumor tissue and stained for CD206 and IFN- $\gamma$ with immunofluorescent antibodies. Immunofluorescence staining (x200) shown for IFN- $\gamma$ deposition and CD $206^{+}$macrophages.

FM3A cell allografts, and combination treatment with HS-1793 and 4 Gy exerted a significant inhibitory effect on tumor growth (Fig. 7B and C). In particular, HS-1793 (1 mg/kg) treatment exerted an $89 \%$ inhibition of tumor growth in the irradiated tumor bearing mice. These results demonstrate that combining HS-1793 with radiotherapy is effective at inducing antitumor immunity.

\section{Discussion}

An important goal of novel agents acting on novel targets in cancer treatment is the induction of apoptosis or the debilitation of cancer cells without excessive damage to normal cells. Interest in bioactive compounds on cancer treatments and prevention has steadily increased over the past two decades and the majority of these compounds that exhibit chemopreventive activity have been identified in vegetables, fruits, barks, leaves, spices and grains (33). Naturally occurring bioactive compounds can potentially be useful in complementary therapy for breast cancer patients (34). Recently, the combination of natural products with either chemotherapy or radiotherapy has been shown to improve outcomes for breast cancer and it is a useful strategy for patients with late-stage breast cancer who cannot be treated with surgery $(35,36)$. Radiotherapy has often been associated with the recurrence or metastasis of cancer as radiation induces the resistance of tumor cells and in addition, damages healthy cells $(28,37)$. Thus, a number of combination therapies have been developed to overcome radiation-induced resistance, and a large number of clinical trials investigating novel drugs derived from natural products and radiotherapy combinations have been performed $(38,39)$.

HS-1793 is a resveratrol derivative and several studies have demonstrate that it has more potent anticancer activity than its parent compound. It is also not any highly cytotoxic than resveratrol (25). Evidence from in vitro and in vivo studies has indicated that the antitumor effects of HS-1793 are mediated through apoptosis in a number of different cancer cell lines $(25,26,40)$ and through the induction of antitumor immune responses by modifying the balance between effector $\mathrm{T}$ cells and immune suppressive cells in a mouse breast tumor model $(26,29)$. In addition, in a previous study by the authors, it was demonstrated that HS-1793 enhanced the radiosensitivity of mouse breast cancer cells under hypoxic conditions (27). In the present study, the results demonstrated that HS-1793 not only enhanced the radiation-induced death of FM3A cells, but also inhibited tumor growth in FM3A cell allografts when compared to radiation or treatment with the compound alone. Thus, these data suggest that HS-1793 may be a potential candidate for use in combination with radiotherapy.

The exposure of cells to ionizing radiation results in a range of DNA damage, including strand breaks, base damage and crosslinking, which in turn induces apoptosis in radiation-sensitive tissues, including lymphocytes $(41,42)$. The 

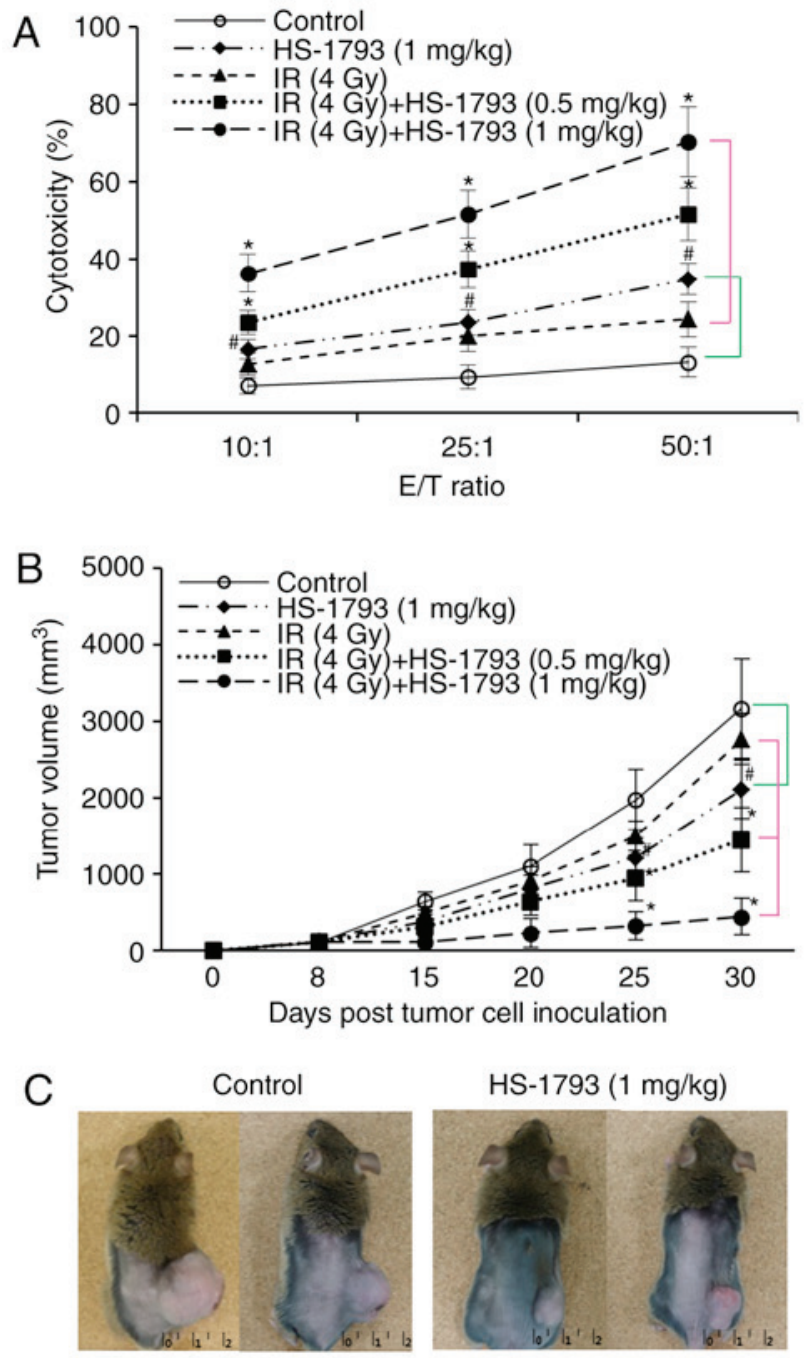

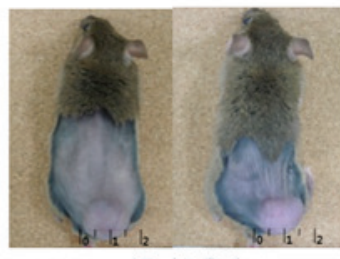

IR (4 Gy)

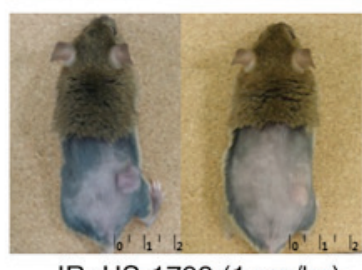

IR+HS-1793 (1 mg/kg)
Figure 7. Anti-tumor activity of HS-1793 in irradiated tumor bearing mice. FM3A cells $\left(2 \times 10^{6}\right.$ cells $\left./ 50 \mu 1\right)$ were inoculated subcutaneously on the right flank of female $\mathrm{C} 3 \mathrm{H} / \mathrm{He}$ mice. At a tumor size of $80-125 \mathrm{~mm}^{3}$, the mice were treated with intraperitoneal injections of HS-1793 $(0.5$ and $1 \mathrm{mg} / \mathrm{kg})$ and were irradiated with $4 \mathrm{~Gy}$. After $24 \mathrm{~h}$, the mice were treated with HS-1793 twice a week for 3 weeks. (A) The cytotoxicity of splenocytes against target FM3A tumor cells was measured with LDH release assaying kit. (B) For the evaluation of combination effects of HS-1793 and radiation, a single inoculation of tumor cells was performed simultaneously with intraperitoneal injections of HS-1793 twice a week after irradiation for 3 weeks. Tumor size was assessed weekly. Data reported as the means \pm SD from 5 mice per group. (C) Representative photographs of mouse with tumor in each group are shown. ${ }^{\#} \mathrm{P}<0.05$ as compared with the control and ${ }^{*} \mathrm{P}<0.05$ as compared with irradiation alone (IR); one-way analysis of variance with Tukey's post hoc test.

reduction in the number of lymphocytes is associated with immunosuppressive functions in cancer patients treated with radiotherapy. The induction of a systemic antitumor immune response involves the coordinated participation of several different $\mathrm{T}$ lymphocytes. In particular, cytotoxic $\mathrm{CD} 8^{+} \mathrm{T}$ lymphocytes are usually responsible for the direct killing of tumor cells and the $\mathrm{CD}^{+} \mathrm{T}$ lymphocyte subpopulation is also required for the induction of an efficient antitumor immune response $(43,44)$. A small fraction of $\mathrm{CD}^{+}$cells known as Tregs, express CD25 and Foxp3 on the cell surface, and are considered to be suppressive elements of the immune system. They have been shown to be involved directly or indirectly in tumor progression by modulating certain constituents of the tumor microenvironment $(11,45)$. Ionizing radiation is associated with immunosuppressive functions as Tregs are more resistant to radiation than other lymphocytes $(46,47)$. A previous study demonstrated that HS-1793 exerted radioprotective effects through the inhibition of cellular DNA damage (28). In this light, it is critical to investigate whether HS-1793 can provide protection against the radiation-induced damage of lymphocytes and overall immune suppression in irradiated tumor-bearing mice.

In the present study, it was demonstrated that HS-1793 increased lymphocyte proliferation with or without Con A stimulation in irradiated tumor-bearing mice via the inhibition of DNA damage to lymphocytes Moreover, HS-1793 treatment decreased the proportion of Tregs in irradiated tumor-bearing mice when compared to the controls or irradiation alone. Radiation affects the function of Tregs by altering the expression of cellular activation markers and by regulating cytokine expression within the tumor microenvironment (18). Indeed, IL-4 is essential for naturally occurring Treg homeostasis or activation, and Tregs are refractory to TCR (T cell receptor)-induced proliferation (48). In addition, IL-4 inhibits TGF- $\beta$-induced Foxp3 expression and thus suppresses the generation of new Foxp $3^{+}$Tregs (49). Importantly, TGF- $\beta$ is strongly induced by radiation as an immunosuppressive factor and is known to activate Tregs rather than effector $\mathrm{T}$ cells $(46,50)$. IL-10 also potentiates the differentiation of human induced Treg cells via STAT3 and Foxo1 (51). In a previous study, it was demonstrated that HS-1793 promoted IL-4 secretion in tumor-derived T lymphocytes and immunosuppressive cytokines, such as TGF- $\beta(26,29)$. In the present study, it was found that the administration of HS-1793 increased IL-4 production, and decreased TGF- $\beta$ and IL-10 production in irradiated tumor-bearing mice. These data suggest that HS-1793 plays an important role in the downregulation of activated Tregs by radiotherapy.

Cancer cells promote the recruitment of Tregs, specific subsets of TAMs and myeloid-derived suppressor cells (MDSCs), via the secretion of TGF- $\beta$ or IL-10 (10,52). TAMs have been shown to inhibit the development of efficient antitumor responses, and in doing so they promote tumor growth, invasion, metastasis and activate tumor-promoting genes in cancer cells. In particular, TAMs of the M2 phenotype exhibit a high expression of CD68, CD204, CD206, vascular endothelial growth factor (VEGF) and matrix metalloproteinase (MMP)-9 (52). In addition, TAMs effectively inhibit the induction of proper antitumor $\mathrm{T}$ cell responses through the production of immunosuppressive cytokines, such as TGF- $\beta$ and IL-10, which promote the induction and infiltration of $\mathrm{CD} 4{ }^{+} \mathrm{CD} 25^{+} \mathrm{FoxP}^{+} \mathrm{T}$ cells (Tregs) at the tumor site $(33,52)$. The authors previously reported that HS-1793 administration significantly increased IFN- $\gamma$-expressing $\mathrm{CD}^{+} \mathrm{T}$ cells in splenocytes, as well as in tumor tissue and CD206 ${ }^{+}$macrophage infiltration was decreased at the tumor site with a higher 
expression of IFN- $\gamma$. In addition, IFN- $\gamma$ led to the switch of the established human TAMs from the M-2 to M-1 phenotype. IFN- $\gamma$ re-treated TAMs secreted lower levels of mediators with immunosuppressive and/or pro-tumoral properties, such as IL-10, TGF- $\beta$, VEGF and MMP-9 than untreated M-2 phenotype TAMs (29). In the present study, it was demonstrated that HS-1793 in combination with radiation decreased CD206 ${ }^{+}$ macrophage infiltration in the tumor site when compared to the control or radiation alone. However, there was no difference in $\mathrm{CD}_{206^{+}}$macrophage infiltration in the tumor site between the unirradiated and irradiated controls. These results were also supported by the increased IFN- $\gamma$-expressing $\mathrm{CD}^{+} \mathrm{T}$ cells in splenocytes of tumor-bearing mice and in tumor tissue following the combination of HS-1793 and radiation. IFN- $\gamma$ plays a key role in tumor surveillance and immunoediting and blocks TGF- $\beta$-mediated Treg cell differentiation (29). In addition, IFN- $\gamma$ producing $\mathrm{CD} 8^{+} \mathrm{T}$ cells (cytotoxic $\mathrm{T}$ lymphocytes; CTL) which kill tumor cells and impede tumor growth are observed as a reflection of a tumor-related immune responses and are recognized as the principal effectors of a local anti-tumor immune response (29). As demonstrated in the present study, the combination of HS-1793 and radiation significantly increased IFN- $\gamma$-expressing $C D 8^{+} \mathrm{T}$ cells in splenocytes and enhanced IFN- $\gamma$ secretion and cytotoxicity against tumor cells, which may be related to HS-1793-induced Treg depletion. More importantly, HS-1793 administration markedly improved radiation-induced tumor growth inhibition in the murine breast cancer model. These results indicate that there seems to be an association between the presence of immunosuppressive cells, such as Tregs or TAMs and the capacity to develop an antitumor immune response by HS-1793 supplementation in the radiation-induced tumor microenvironment.

Tumor heterogeneity is one of the hallmarks of malignancy. Although the present study was limited as it evaluated only FM3A murine breast cancer cells, HS-1793 was shown to be a promising candidate when used in combination with radiotherapy to modulate the tumor microenvironment and promote immunotherapy in breast cancer. Given the intertumor heterogeneity and intratumoral heterogeneity that are considered to account for the differences in clinical behavior and treatment responses in breast cancer, a further potential strategy to overcome treatment resistance such as targeting mutations would be required.

\section{Acknowledgements}

Not applicable.

\section{Funding}

The present study was supported by the Dong-A University research fund and the Dongnam Institute of Radiological and Medical Sciences (DIRAMS) grant funded by the Korea government (MSIT) (nos. 50493-2014 and 50496-2019).

\section{Availability of data and materials}

All data generated during this research are included in this article or are available on proper request from the corresponding authors.

\section{Authors' contributions}

JSK, WSJ and MHJ were involved in the conceptualization of the study and in the methodology. CGL, YRK, SKJ and SJO performed the experiments. WSJ and MHJ were involved in data analysis, and in the writing and preparation of the original draft. JSK, WSJ and MHJ were involved in the writing, reviewing and editing of the manuscript. WSJ and MHJ supervised the study. MHJ was involved in funding acquisition. All the above-mentioned authors participated in the conception and design of the study. All authors have read and approved the final manuscript.

\section{Ethics approval and consent to participate}

The animal experiments were ethically approved by the Committee on Use and Care of Animals of Dong-A University Hospital (DIACUC-10-14) and Dong Nam Institute of Radiological and Medical Sciences (DIRAMS AEC-2011-003).

\section{Patient consent for publication}

Not applicable.

\section{Competing interests}

The authors declare that they have no competing interests.

\section{References}

1. Basu P and Maier C: Phytoestrogens and breast cancer: In vitro anticancer activities of isoflavones, lignans, coumestans, stilbenes and their analogs and derivatives. Biomed Pharmacother 107: 1648-1666, 2018.

2. Clarke M, Collins R, Darby S, Davies C, Elphinstone P, Evans V, Godwin J, Gray R, Hicks C, James S, et al: Effects of radiotherapy and of differences in the extent of surgery for early breast cancer on local recurrence and 15-year survival: An overview of the randomised trials. Lancet 366: 2087-2106, 2005.

3. Turashvili G and Brog E: Tumor heterogeneity in breast cancer. Front Med (Lausanne) 4: 227, 2017.

4. Grantzau T and Overgaard J: Risk of second non-breast cancer after radiotherapy for breast cancer: A systematic review and meta-analysis of 762,468 patients. Radiother Oncol 114: 56-65, 2015.

5. Bartelink H, Horiot JC, Poortmans PM, Struikmans H, Van den Bogaert W, Fourquet A, Jager JJ, Hoogenraad WJ, Oei SB, Wárlám-Rodenhuis CC, et al: Impact of a higher radiation dose on local control and survival in breast-conserving therapy of early breast cancer: 10-Year results of the randomized boost versus no boost EORTC 22881-10882 trial. J Clin Oncol 25: 3259-3265, 2007.

6. Balogh A, Persa E, Bogdándi EN, Benedek A, Hegyesi H, Sáfrány $\mathrm{G}$ and Lumniczky $\mathrm{K}$ : The effect of ionizing radiation on the homeostasis and functional integrity of murine splenic regulatory T cells. Inflamm Res 62: 201-212, 2013.

7. Deng G: Tumor-infiltrating regulatory $\mathrm{T}$ cells: Origins and features. Am J Clin Exp Immunol 7: 81-87, 2018.

8. Stanton SE and Disis ML: Clinical significance of tumor-infiltrating lymphocytes in breast cancer. J Immunother Cancer 4: 59, 2016.

9. Loi S, Sirtaine N, Piette F, Salgado R, Viale G, Van Eenoo F, Rouas G, Francis P, Crown JP, Hitre E, et al: Prognostic and predictive value of tumor-infiltrating lymphocytes in a phase III randomized adjuvant breast cancer trial in node-positive breast cancer comparing the addition of docetaxel to doxorubicin with doxorubicin-based chemotherapy: BIG 02-98. J Clin Oncol 31: 860-867, 2013.

10. Takeya M and Komohara Y: Role of tumor-associated macrophages in human malignancies: Friend or foe? Pathol Int 66: 491-505, 2016. 
11. Chen X, Du Y, Lin X, Qian Y,Zhou T and Huang Z: CD4+CD25+ regulatory $\mathrm{T}$ cells in tumor immunity. Int Immunopharmacol 34 : 244-249, 2016.

12. Cassetta L and Pollard JW: Repolarizing macrophages improves breast cancer therapy. Cell Res 27: 963-964, 2017.

13. Shou J, Zhang Z, Lai Y, Chen Z and Huang J: Worse outcome in breast cancer with higher tumor-infiltrating FOXP3+ Tregs : A systematic review and meta-analysis. BMC Cancer 16: 687, 2016

14. Peranzoni E, Lemoine J, Vimeux L, Feuillet V, Barrin S, Kantari-Mimoun C, Bercovici N, Guérin M, Biton J, Ouakrim H, et al: Macrophages impede CD8 T cells from reaching tumor cells and limit the efficacy of anti-PD-1 treatment. Proc Natl Acad Sci USA 115: E4041-E4050, 2018.

15. Buchan SL, Dou L, Remer M, Booth SG, Dunn SN, Lai C, Semmrich M, Teige I, Mårtensson L, Penfold CA, et al: Antibodies to costimulatory receptor 4-1BB enhance anti-tumor immunity via T regulatory cell depletion and promotion of CD8 T cell effector function. Immunity 49: 958-970 e957, 2018.

16. Hao NB, Lu MH, Fan YH, Cao YL, Zhang ZR and Yang SM: Macrophages in tumor microenvironments and the progression of tumors. Clin Dev Immunol 2012: 948098, 2012.

17. Ahmed MM, Guha C, Hodge JW and Jaffee E: Immunobiology of radiotherapy: New paradigms. Radiat Res 182: 123-125, 2014

18. Lumniczky K and Safrany G: The impact of radiation therapy on the antitumor immunity: Local effects and systemic consequences. Cancer Lett 356: 114-125, 2015.

19. Kulkarni SS and Canto C: The molecular targets of resveratrol. Biochim Biophys Acta 1852: 1114-1123, 2015.

20. Zhao Y, Tang H, Zeng X, Ye D and Liu J: Resveratrol inhibits proliferation, migration and invasion via Akt and ERK1/2 signaling pathways in renal cell carcinoma cells. Biomed Pharmacother 98: 36-44, 2018.

21. Elshaer M, Chen Y, Wang XJ and Tang X: Resveratrol: An overview of its anti-cancer mechanisms. Life Sci 207: 340-349, 2018.

22. Scarlatti F, Sala G, Ricci C, Maioli C, Milani F, Minella M, Botturi M and Ghidoni R: Resveratrol sensitization of DU145 prostate cancer cells to ionizing radiation is associated to ceramide increase. Cancer Lett 253: 124-130, 2007.

23. Yang Y, Paik JH, Cho D, Cho JA and Kim CW: Resveratrol induces the suppression of tumor-derived CD4+CD25+ regulatory T cells. Int Immunopharmacol 8: 542-547, 2008.

24. Baatout S, Derradji H, Jacquet P, Ooms D, Michaux A and Mergeay M: Enhanced radiation-induced apoptosis of cancer cell lines after treatment with resveratrol. Int J Mol Med 13: 895-902, 2004.

25. Jeong SH, Jo WS, Song S, Suh H, Seol SY, Leem SH, Kwon TK and Yoo YH: A novel resveratrol derivative, HS1793, overcomes the resistance conferred by Bcl-2 in human leukemic U937 cells. Biochem Pharmacol 77: 1337-1347, 2009.

26. Jeong MH, Yang KM, Choi YJ, Kim SD, Yoo YH, Seo SY Lee SH, Ryu SR, Lee CM, Suh Hs and Jo WS: Resveratrol analog, HS-1793 enhance anti-tumor immunity by reducing the CD4+CD25+ regulatory T cells in FM3A tumor bearing mice. Int Immunopharmacol 14: 328-333, 2012.

27. Choi YJ, Heo K, Park HS, Yang KM and Jeong MH: The resveratrol analog HS-1793 enhances radiosensitivity of mouse-derived breast cancer cells under hypoxic conditions. Int J Oncol 49: 1479-1488, 2016

28. Jeong MH, Yang KM, Jeong DH, Lee CG, Oh SJ, Jeong SK, Lee KW, Jo YR and Jo WS: Protective activity of a novel resveratrol analogue, HS-1793, against DNA damage in ${ }^{137} \mathrm{Cs}$-irradiated CHO-K1 cells. J Radiat Res 55: 464-475, 2014.

29. Jeong SK, Yang K, Park YS, Choi YJ, Oh SJ, Lee CW, Lee KY, Jeong MH and Jo WS: Interferon gamma induced by resveratrol analog, HS-1793, reverses the properties of tumor associated macrophages. Int Immunopharmacol 22: 303-310, 2014.

30. Wang WJ, Long LM, Yang N, Zhang QQ, Ji WJ, Zhao JH, Qin ZH, Wang Z, Chen G and Liang ZQ: NVP-BEZ235, a novel dual $\mathrm{PI} 3 \mathrm{~K} / \mathrm{mTOR}$ inhibitor, enhances the radiosensitivity of human glioma stem cells in vitro. Acta Pharmacol Sin 34: 681-690, 2013

31. Eberlein U, Scherthan H, Bluemel C, Peper M, Lapa C, Buck AK, Port $\mathrm{M}$ and Lassmann $\mathrm{M}$ : DNA damage in peripheral blood lymphocytes of thyroid cancer patients after radioiodine therapy. J Nucl Med 57: 173-179, 2016.

32. Zhu Q, Wu X, Wu Y and Wang X: Interaction between Treg cells and tumor-associated macrophages in the tumor microenvironment of epithelial ovarian cancer. Oncol Rep 36: 3472-3478, 2016.
33. Xu DP, Li Y, Meng X, Zhou T, Zhou Y, Zheng J, Zhang JJ and Li HB: Natural antioxidants in foods and medicinal plants: Extraction, assessment and resources. Int J Mol Sci 18: E96, 2017.

34. Sinha D, Sarkar N, Biswas J and Bishayee A: Resveratrol for breast cancer prevention and therapy: Preclinical evidence and molecular mechanisms. Semin Cancer Biol 40-41: 209-232, 2016.

35. da Costa Araldi IC, Bordin FPR, Cadona FC, Barbisan F, Azzolin VF, Teixeira CF, Baumhardt T, da Cruz IBM, Duarte MMMF and Bauermann LF: The in vitro radiosensitizer potential of resveratrol on MCF-7 breast cancer cells. Chem Biol Interact 282: 85-92, 2018

36. Dewangan J, Tandon D, Srivastava S, Verma AK, Yapuri A and Rath SK: Novel combination of salinomycin and resveratrol synergistically enhances the anti-proliferative and pro-apoptotic effects on human breast cancer cells. Apoptosis 22: 1246-1259, 2017.

37. Barker HE, Paget JT, Khan AA and Harrington KJ: The tumour microenvironment after radiotherapy: Mechanisms of resistance and recurrence. Nat Rev Cancer 15: 409-425, 2015.

38. Sharma RA, Plummer R, Stock JK, Greenhalgh TA, Ataman O, Kelly S, Clay R, Adams RA, Baird RD, Billingham L, et al: Clinical development of new drug-radiotherapy combinations. Nat Rev Clin Oncol 13: 627-642, 2016.

39. Malik A, Sultana M, Qazi A, Qazi MH, Parveen G, Waquar S, Ashraf AB and Rasool M: Role of natural radiosensitizers and cancer cell radioresistance: An update. Anal Cell Pathol (Amst) 2016: 6146595, 2016.

40. Jeong SH, Lee JS, Jeong NY, Kim TH, Yoo KS, Song S, Suh H, Kwon TK, Park BS and Yoo YH: A novel resveratrol analogue HS-1793 treatment overcomes the resistance conferred by Bcl-2 and is associated with the formation of mature PML nuclear bodies in renal clear cell carcinoma Caki-1 cells. Int J Oncol 35: 1353-1360, 2009

41. Cerda H, Delincee H, Haine H and Rupp H: The DNA 'comet assay' as a rapid screening technique to control irradiated food. Mutat Res 375: 167-181, 1997.

42. Bausinger J and Speit G: The impact of lymphocyte isolation on induced DNA damage in human blood samples measured by the comet assay. Mutagenesis 31: 567-572, 2016.

43. Makkouk A and Weiner GJ: Cancer immunotherapy and breaking immune tolerance: New approaches to an old challenge. Cancer Res 75: 5-10, 2015.

44. Shiku H: Importance of CD4+ helper T-cells in antitumor immunity. Int J Hematol 77: 435-438, 2003.

45. Shen Y, Wei Y, Wang Z, Jing Y, He H, Yuan J, Li R, Zhao Q, Wei $\mathrm{L}$, Yang $\mathrm{T}$ and Lu J: TGF- $\beta$ regulates hepatocellular carcinoma progression by inducing Treg cell polarization. Cell Physiol Biochem 35: 1623-1632, 2015.

46. Son CH, Bae JH, Shin DY, Lee HR, Jo WS, Yang K and Park YS: Combination effect of regulatory T-cell depletion and ionizing radiation in mouse models of lung and colon cancer. Int J Radiat Oncol Biol Phys 92: 390-398, 2015.

47. Kachikwu EL, Iwamoto KS, Liao YP, DeMarco JJ, Agazaryan N, Economou JS, McBride WH and Schaue D: Radiation enhances regulatory $\mathrm{T}$ cell representation. Int J Radiat Oncol Biol Phys 81: 1128-1135, 2011.

48. Yang WC, Hwang YS, Chen YY, Liu CL, Shen CN, Hong WH, Lo SM and Shen CR: Interleukin-4 supports the suppressive immune responses elicited by regulatory $\mathrm{T}$ cells. Front Immunol 8: 1508, 2017.

49. Dardalhon V, Awasthi A, Kwon H, Galileos G, Gao W, Sobel RA, Mitsdoerffer M, Strom TB, Elyaman W, Ho IC, et al: IL-4 inhibits TGF-beta-induced Foxp3+ T cells and, together with TGF-beta, generates IL-9+ IL-10+ Foxp3(-) effector T cells. Nat Immunol 9: 1347-1355, 2008.

50. Martin M, Lefaix J and Delanian S: TGF-betal and radiation fibrosis: A master switch and a specific therapeutic target? Int J Radiat Oncol Biol Phys 47: 277-290, 2000.

51. Hsu P, Santner-Nanan B, Hu M, Skarratt K, Lee CH, Stormon M, Wong M, Fuller SJ and Nanan R: IL-10 Potentiates Differentiation of Human Induced Regulatory T Cells via STAT3 and Foxo1. J Immunol 195: 3665-3674, 2015.

52. Solinas G, Germano G, Mantovani A and Allavena P: Tumor-associated macrophages (TAM) as major players of the cancer-related inflammation. J Leukoc Biol 86: 1065-1073, 2009.

This work is licensed under a Creative Commons Attribution-NonCommercial-NoDerivatives 4.0 International (CC BY-NC-ND 4.0) License. 